International Journal of Child, Youth and Family Studies (2011) 3 \& 4: 353-360

\title{
PREFACE: \\ SOCIAL JUSTICE IN CHILD, YOUTH AND FAMILY STUDIES
}

\author{
Shannon A. Moore
}

\begin{abstract}
This special issue of the International Journal of Child, Youth and Family Studies offers critical insights into contemporary social justice issues impacting the lives of children and young people, their caregivers, and their communities. The authors write from a range of fields as they question taken-forgranted knowledges within social work, child welfare, health promotion, psychology, sociology, education, human rights, and women's studies. As such, the collection includes feminist, post-colonial, post-structural, and post-modern analyses organized through an editorial standpoint of critical pedagogy. The preface offers additional insights into my own personal, professional, epistemological, and pedagogical locations that illuminate my role of guest editor, and further contextualizes the transdisciplinary selection of manuscripts within a social justice discourse.
\end{abstract}

Keywords: social justice; child, youth and family studies; careers; transdisciplinary critical pedagogy

Shannon A. Moore, Ph.D. is Director, Centre for Women's Studies and Associate Professor in the Department of Child and Youth Studies at Brock University.

Correspondence concerning this article should be addressed to Shannon Moore, Department of Child and Youth Studies, Brock University, 500 Glenridge Avenue, St. Catharines, Ontario, Canada, L2S 3A1. Contact: smoore@brocku.ca 
International Journal of Child, Youth and Family Studies (2011) 3 \& 4: 353-360

The selection of articles in this volume focuses on social justice issues within child, youth, and family studies, and has been shaped by my epistemological and personal standpoint. Specifically, this standpoint comes from a feminist perspective wherein gender and power relations can be seen to impact our ways of knowing, and further, situate the knower as a researcher, a pedagogue, and in my instance, as a practitioner (Harding, 1986, 1991, 2004; Hartsock, 1983; Smith, 1987, 2005). As Levison (2000) further explains, there is a clear relationship between the visibility of women's ways of knowing and children's perspectives: "There is a striking parallel between the evolution of feminist research....to gendered analysis and feminist standpoint theory - and emerging directions for studies of children and childhood” (p. 126). I hold a Ph.D. in Counselling Psychology and since 2000 have been a registered clinical counsellor and psychotherapist in Canada. From this foundation, I integrated feminist and indigenous epistemologies that for me formed a transdisciplinary theoretical foundation for praxis in service delivery systems across Canada, Scotland, and England. Moreover, as the mother of two young children, my viewpoint has been shaped by two decades of counselling the children, young people, and caregivers who have accessed the various social service systems where I have found employment. These lenses shape how I ask questions and seek answers about social justice issues within the "spaces of childhood" (Moss \& Petrie, 2002).

In an effort to move from the epistemological (and ontological) debates over contested definitions of social justice, I take this premise forward: Social justice is the act of raising awareness of injustice, and taking action to address inequities with the aim of creating a world with less suffering (Moore, 2008). This definition is associated with notions of praxis discussed in the work of critical educator Paulo Freire $(1970,1985)$ who began as a teacher in poverty-stricken northeastern Brazil during the 1960s, and was introduced to North Americans through his seminal text, Pedagogy of the Oppressed (Freire, 1970). By raising political awareness, he proposed an approach to education that is focused on critical reflection and praxis. Critical pedagogues encourage individuals "to think, to reflect, and to act, in order to create a more democratic egalitarian society” (Kaufmann, 2000, p. 432; see also Moore, 2006). They also propose that the responsibilities of those who have privilege in society include actions leading to greater social justice for marginalized individuals and groups. In line with critical educators Henry Giroux and Susan Searls Giroux, for me this means "academics need to connect their work to a larger public and assume a measure of responsibility in naming, struggling against, and alleviating human suffering” (Giroux \& Searls Giroux, 2004, p. 84). Critical pedagogues are challenged to open up safer spaces for criticality, and in so doing, attempt to be agents of change by taking risks (Moore, 2006; Moore \& Mitchell, 2008; Mitchell \& Moore, 2008). These scholars are aware that practitioners, educators, and academics are faced with complex decisions concerning social justice, democracy, and competing ethical claims in all aspects of their work (Kincheloe, 2005). Moreover, they engage liberation pedagogy with the intention of creating more democratic and egalitarian societies through their actions as educators and citizens (Moore, 2006). 
International Journal of Child, Youth and Family Studies (2011) 3 \& 4: 353-360

This critical yet optimistic stance focuses on illuminating the nexus of power and knowledge hidden in both academic and policy texts shaping interventions in the lives of young people and families. (In this issue, see the contributions of Stevens and Ajandi for further discussion). As Sevenhuijsen (1998, p. 123) has affirmed, such texts are "sites of power”. She further observes:

By establishing conventions, authoritative repertoires of interpretation and frameworks of argumentation and communication, they confer power upon preferred modes of speaking and judging, and upon certain ways for expressing moral and political subjectivity. Through examining official documents in this way it becomes possible to trace both the overt and hidden gender load in their vocabulary. (also cited in Moss \& Petrie, 2002, p. 81)

Once again, Sevenhuijsen directs our attention to challenging the taken-forgranted knowledges embedded within childhood studies. Historically, childhood professional training has been dominated by developmental psychologists and notions of "the child" divorced from culture, community and history, presenting not as competent or powerful, but as a future investment, or an adultist abstraction rooted in the medical model (Aitken, 2001; see also Mitchell, 2003; Burman, 2008a, 2008b, 2008c). These categorizations reflect a type of modernist "arborescent thought" thus reinforcing notions of lesser power and passivity for young people, and not infrequently, the women providing the bulk of their care:

The study of children and childhood has historically been accorded a marginal place in the health, human, and social sciences. In part, this is due to prevailing Western ideology that constructs children as passive, presocial, innocent, and vulnerable. The dominant discourse is further characterized by the treatment of children as a homogeneous group, devoid of race, class, or gender. (Berman, 2003, p. 102)

In medical literature and developmental psychology, ideas are generally understood to have originated as universal truths. This quest for the ultimate axiom has been associated with masculine epistemologies and the establishment of binary positions suspended in confrontation and struggles for domination. By contrast, feminist epistemologies are often drawn towards connectedness, continuities, convergence, and relational constructions (Hartstock, 1983). (In this issue, see Madan for further discussion). Again as Sevenhuijsen (1998) has suggested, the inclusion of a feminist ethic of care and relational vocabulary shapes different questions and answers about childhood making it more likely we will develop new conceptions of what constitutes social justice. This conceptualization of a gendered, fluid, and socially constructed world view has been described as "rhizomatic" thought in contradistinction to the set trajectory of arborescent thought (Jung, 1956; see also Holmes \& Gastaldo, 2004; Deleuze \& Guattari, 1987; Moore, 2006; Moore \& Mitchell, 2008).

Socially constructed knowledge has established a solid foundation in sociological discourse throughout the 1980s and is integral to understanding the sociology of 
International Journal of Child, Youth and Family Studies (2011) 3 \& 4: 353-360

childhood (James \& Prout, 1990; Jenks, 1996; Matthews, 2007; see also Mitchell in this issue for further discussion) and more critical psychological perspectives (Burman, 2008a; in this issue, see Grondin for further discussion). Matthews (2007) has explained the epistemology of such historically and culturally situated forms of knowledge as follows:

Both the socialization and the developmental psychology perspectives push scholars to write about children as if all children were the same regardless of social location or context. The "new" sociological perspective stresses "the plurality of childhoods" not only with the same society but also across the settings in which children conduct their everyday lives ... Historical and anthropological research provides strong evidence that the nature of childhood and children varies through time and across society. (p. 325)

The au courant notion of the "social studies of childhood" (Matthews, 2007, p. 330; see also Prout, 2005) now draws attention to a merger of far-ranging disciplines from anthropology, cultural studies, psychology, history, education, and law, as well as sociology (Montgomery, Burr, \& Woodhead, 2003; in this issue, see also Mitchell for further discussion). Similarly, Burman $(1995,1996)$ has encouraged scholars to investigate the linkages between women and children in particular by experimenting in disciplinary and cultural tourism.

My experience as a counsellor for children and their carers (and most particularly within mental health settings) has shown me that there is an inverse relationship between the number of professionals intervening in young people's lives and the positive outcomes that one may expect. In this way, I have observed that young people are more likely to "fall through the cracks" of service delivery systems if professionals charged with their care hold tight to disciplinary knowledge and power. The impact is massive as collaboration, knowledge exchange, and socially just action become paralyzed (see Moore \& Mitchell, 2009, p. 36). Disciplinary boundaries are another artifact of the modernist notion of truth that holds only that which can be objectively evaluated in the greatest esteem:

In truth there is little that is merely measurable ... there is an inverse relationship between importance and what can be easily measured. The deeper we venture beneath the surface, the more profound the moral and spiritual character of learning and the more elusive the measurement becomes (Scottish Council Foundation, as cited in Moss \& Petrie, 2002, p. 67).

Thus, as Levison (2000) claims, if our aim is to improve the quality of knowledge creation in childhood studies and extant practice within professional settings, we must move away from "rigid disciplinary boundaries and limiting entry points for ideas" (p. 131) towards a transdisciplinary study of childhood (Mitchell \& Moore, 2008; Moore \& Mitchell, 2009). As Klein (2004) explains, "The problems of society are increasingly complex and interdependent. Hence, they are not isolated to particular sectors or 
disciplines, and they are not predictable. They are emergent phenomena with non-linear dynamics, uncertainties...” (p. 517).

Transdisciplinarity involves moving beyond all disciplines "into a fabulous space of new knowledge” (Nicolescu, 2005, p. 3). It concerns emergent new thinking, new ways of accessing old ways of thinking, construction of new ways of knowing, and praxis in order to transcend tired, dichotomous critiques (Moore \& Mitchell, 2008). Transdisciplinary approaches to science, politics, education, and cultural studies of media and the arts sharply contrast multi- or even inter-disciplinary methodologies, and are fundamentally associated with critique. A transdisciplinary epistemology (Moore, 2006; Moore \& Mitchell, 2008, 2009) - defined as a “deep interdisciplinarity” by Kincheloe and McLaren (2005) - holds key ontological concerns for "the relationship between individuals and their social contexts" where an "ever evolving criticality ... does not determine how we see the world but helps us devise questions and strategies” for exploring our social spheres (Kincheloe \& McLaren, 2005, pp. 303-342). The idea is to create spaces for plurality, diversity, and opportunity to encourage open dialogue about counter-hegemonic processes. Moreover, through transdisciplinary critical pedagogy (Moore, 2006), voices and social issues from the margins enter active discourse to promote critical inquiry, consideration of multiple viewpoints and perspectives in dialogue with others, and engagement of socially just actions (in this issue, see Moore, Gegieckas, Marval, McCauley, \& Peloquin; Pon, Gosine, \& Phillips; de Finney, Dean, Loiselle, \& Saraceno for further discussion).

As guest editor for this special issue, I have taken real pleasure in my "responsibility ... to provide a space where the complexity of knowledge, culture, values and social issues can be explored in open and critical dialogue through a vibrant culture of questioning” (Giroux \& Searls Giroux, 2004, p. 243). Readers are now invited to consider the following multiple viewpoints and perspectives in a dialogue with the contributors, and to move from simple contention towards a positive transformation of the world around them (Nagda, Gurin, \& Lopez, 2003; hooks, 2003). 
International Journal of Child, Youth and Family Studies (2011) 3 \& 4: 353-360

\section{References}

Aitken, S. C. (2001). Global crises of childhood: Rights, justice and the unchild like child. Area, 33(2), 119-127.

Berman, K. (2003). Getting critical with children: Empowering approaches with a disempowered group. Advances in Nursing Science, 26(2), 112-113.

Burman, E. (1995). What is it? Masculinity and femininity and the cultural representation of childhood. In S. Wilkinson \& C. Kitzinger (Eds.), Feminism and discourse (pp. 49-67). London: Sage.

Burman, E. (1996). Local, global or globalised? Child development and international child rights legislation. Childhood: A Global Journal of Child Research, 3(1), 45-66.

Burman, E. (2008a). Beyond ‘women vs. children’ or ‘women and children':

Engendering childhood and reformulating motherhood. International Journal of Children's Rights, 16(2), 177-194.

Burman, E. (2008b). Beyond the baby and the bathwater: Postdualistic developmental psychologies for diverse childhoods. In Developments: Child, Image, Nation (pp. 145-161). New York: Routledge.

Burman, E. (2008c). Deconstructing developmental psychology (2nd ed.). New York: Routledge.

Deleuze, G., \& Guattari, F. (1987). A thousand plateaus. Minneapolis: University of Minnesota Press.

Freire, P. (1970). Pedagogy of the oppressed. New York: Continuum.

Freire, P. (1985). The politics of education: Culture, power, and liberation. Handley, MA: Bergin \& Garvey.

Giroux, H., \& Searls Giroux, S. (2004). Take back higher education. New York: Palgrave.

Harding, S. (1986). The science question in feminism. Ithaca, NY: Cornell University Press.

Harding, S. (1991). Whose science? Whose knowledge? Thinking from women's lives. Ithaca, NY: Cornell University Press. 
International Journal of Child, Youth and Family Studies (2011) 3 \& 4: 353-360

Harding, S. (2004). The feminist standpoint reader: Intellectual and political controversies. New York: Routledge.

Hartsock, N. (1983). The feminist standpoint: Developing the ground for a specifically feminist historical materialism. In S. Harding \& M. B. Hintikka (Eds.), Discovering reality: Feminist perspectives on epistemology, metaphysics, methodology, and the philosophy of science (pp. 283-310). New York: Kluwer Academic Publishers.

Holmes, D., \& Gastaldo, D. (2004). Rhizomatic thought in nursing: An alternative path for the development of the discipline. Nursing Philosophy, 5, 258-267.

hooks, b. (2003). Teaching community: A pedagogy of hope. London: Routledge.

James, A., \& Prout, A. (1990). Constructing and reconstructing childhood: Contemporary issues in the sociological study of childhood. London: Routledge/Falmer Press.

Jenks, C. (1996). Childhood. London: Routledge.

Jung, C. G. (1956). Symbols of transformation. In H. Read, M. Fordham, G. Adler, \& W. McGuire (Eds.), R. F. C. Hull (Trans.), The collected works of C. G. Jung (Vol. 5). Princeton, NJ: Princeton University Press.

Klein, J. T. (2004). Prospects for transdisciplinarity. Futures, 36(4), 515-526.

Kaufmann, J. (2000). Reading counter-hegemonic practices through a postmodern lens. International Journal of Lifelong Education, 19(5), 430-447.

Kincheloe, J. (2005). Foreword. In L. D. Soto \& B. B. Swadener (Eds.), Power and voice in research with children (pp. 1-6). New York: Peter Lang.

Kincheloe, J., \& McLaren, P. (2005). Rethinking critical theory and qualitative research. In N. Denzin \& Y. Lincoln (Eds.), The Sage handbook of qualitative research (3rd ed., pp. 303-342). Thousand Oaks, CA: Sage.

Levison, D. (2000). Children as economic agents. Feminist Economics, 6(1), 124-134.

Matthews, S. (2007). A window on the "new” sociology of childhood. Sociology Compass, 1(1), 322-334.

Mitchell, R. C. (2003). Ideological reflections on the DSM-IV-R (or pay no attention to that man behind the curtain, Dorothy!), Child and Youth Care Forum, 32(5), 281-298. 
International Journal of Child, Youth and Family Studies (2011) 3 \& 4: 353-360

Mitchell, R. C., \& Moore, S. A. (2008). Introduction: Power, pedagogy and praxisTowards common ground. In S. A. Moore \& R. C. Mitchell (Eds.), Power, pedagogy and praxis: Social justice in the globalized classroom (pp. 1-18). Boston, Rotterdam and Taipei: Sense Publications.

Montgomery, H., Burr, R., \& Woodhead, M. (2003). Changing childhoods: Local and global. Chichester, UK: Wiley.

Moss, P., \& Petrie, P. (2002). From children's services to children's spaces: Public policy, children and childhood. London: Routledge/Falmer.

Moore, S. A. (2006). Transdisciplinary critical multicultural pedagogy in Canadian higher education. In D. Zinga (Ed.), Navigating multiculturalism (pp. 126-139). Newcastle, UK: Cambridge Scholars Press.

Moore, S. A. (2008). Social justice and education in a world fit for children? In J. A. Kentel \& A. Short (Eds.), Totems and taboos, risk and relevance in research on teachers and teaching (pp. 17-29). Boston, Rotterdam and Taipei: Sense Publications.

Moore, S. A. \& Mitchell, R. C. (Eds.). (2008). Power, pedagogy and praxis: Social justice in the globalized classroom. Boston, Rotterdam and Taipei: Sense Publications.

Moore, S. A., \& Mitchell, R. C. (2009). Rights-based restorative justice: Evaluating compliance with international standards. Youth Justice, 9(1), 27-43.

Nagda, B., Gurin, P., \& Lopez, G. (2003). Transformative pedagogy for democracy and social justice. Race Ethnicity and Education, 6(2), 165-191.

Nicolescu, B. (2005). Transdisciplinarity: Past, present and future. Paper presented at Palestra apresentada no II Congresso Mundial de Transdisciplinaridade (Sept. 612, 2005), Vila Velha/Vitória, Brasil, South America. Retrieved from http://cetrans.com.br/novo/textos/transdisciplinarity-past-present-and-future.pdf

Prout, A. (2005). The future of childhood: Towards the interdisciplinary study of children. London: Routledge.

Sevenhuijsen, S. (1998). Citizenship and the ethics of care: Feminist consideration on justice, morality and politics. London: Routledge.

Smith, D. E. (1987). The everyday world as problematic: A feminist sociology. Toronto: University of Toronto Press.

Smith, D. E. (2005). Institutional ethnography: A sociology for people. Oxford: Altamira Press. 